\title{
The Role of Interpreters in Intercultural Communication
}

\author{
Mariya BOLSHAKOVA \\ Ph.D. (in Pedagogy) \\ Associate Professor \\ Theory and Practice of Translation Department \\ Institute of Social Sciences and International Relations \\ Sevastopol State University \\ 33, Universitetskaya str., Sevastopol, 299053, the Russian Federation \\ +7 (978) 748-62-48 \\ marie-mary@yandex.ru
}

\begin{abstract}
Nowadays, in the context of the widespread creation of international organizations, the establishment and strengthening of international relations in the field of politics, economy and culture, intercultural communication, the purpose of which is to minimize problems associated with the cultural and linguistic differences, plays a significant role. This article defines the role of the professional activities of an interpreter in the intercultural communication. The influence of the current intercultural environment on the content of translators' and interpreters' education is analyzed. The authors consider the interpreter's professional qualities necessary for effective communication, including: patriotism, tolerance to social, ethnic and cultural differences, the ability to adapt to different communication situations, a high speed of switching from one language to another, and mental resistance to stressful situations. The inevitable interconnection of language and culture is noted, which becomes the subject of a number of special studies and determines the development of the educational cultural paradigm. The necessity of linguo-cultural competence development in the university in order to minimize failures in intercultural communication is considered. The study allows to conclude that a reorganization of the educational process of interpreters is necessary in order to form an idea of them as a full participant in intercultural communication.
\end{abstract}

Keywords: intercultural communication; interpreter; linguo-cultural competence; higher school; translation; cultural dialogue. 


\section{Introduction}

Today, in the context of implementing international projects, strengthening of international cultural relations, and developing economic cooperation between Russia and other countries, intercultural communication plays an important role. Its goal is to minimize communication disruptions due to the cultural and linguistic characteristics of countries. The number of media is growing, which enhances the role of the interpreter as a mediator between cultures. The profession of interpreter has become popular and prestigious, and institutions where interpreters can be trained are widespread now. The professionalism of the interpreter and his ability to understand and interpret the information are often the groundwork of successfully established international contacts, so the interpreter training should be carried out systematically, efficiently and comply with the modern world requirements.

\section{Methods}

The issues of professional training of interpreters and their role in intercultural communication were considered in the works of many domestic and foreign scientists, such as: Vilen Komissarov (2017), Irina Ieronova (2008), Aleksandr Schweizer (1994) and others. The problem of intercultural competence development in the educational process is regarded as the key one mainly by Irina Khaleeva (1999), Evgeniy Vereshchagin (2005), Efim Passov (2002) and others. The works of these scientists became the basis of this research. The detailed analysis showed that mainly they focus on the linguistic education while other aspects of training do not receive systematic coverage and need consideration.

\section{Results}

The concept of "intercultural communication" was first used in the mid-twentieth century by Edward Hall, the anthropologist from the USA, in the context of his program of adaptation abroad for business people and American diplomats. Intercultural communication is now the type of communication between culture-bearers in some difficult situations caused by differences between these cultures. Such difficulties can be caused both by the language barrier, and by various expectations and prejudices inherent in representatives of those cultures.

The concept of intercultural communication is based on the assumption that under the same circumstances, communicants can experience the same feelings and sensations, which gives them the opportunity to understand other points of view, ideas and various cultural phenomena, i.e. imagine themselves in the role of another person, understand his feelings and actions, accept his 


\section{Dictum Factum}

worldview, and feel the desires. At the same time, intercultural communication is productive and successful when the communicants who are the bearers of different languages and cultures are aware of the fact that each of them is different and each perceives the "foreignness of the partner" (Kadyrova, 2018). Nowadays, the role of the interpreter has expanded significantly and, in addition to fluent speaking the foreign language, it requires "expertise" in the field of intercultural communication.

The current intercultural situation in the world demonstrates the need for interpreter who speak several languages and are able to carry out various forms of intercultural interaction in order to ensure cooperation in solving professional problems, tolerantly perceiving social, ethnic, religious, cultural and other differences (Bolshakova, 2017). A successful interpreter loves his country and, at the same time, is motivated to study the culture of a foreign one; he is morally stable under unpredictable circumstances of intercultural communication, and tolerates social, cultural and ethnic differences that are inevitable in the process of interaction between cultures. Many teachers of translation put mental stability on the first place if regarding the qualities of professional suitability. Forced long speaking, frequent language switching, increased speech rate, the need to focus on other people's thoughts, complete submission to the speaker require the interpreter to have physical and psychological stamina, special volitional qualities, and the ability to find a way out of difficult situations.

Effective intercultural communication of the interpreter provides him with a number of advantages necessary for success. Understanding the principles of intercultural interaction at an early stage helps the interpreter to determine the communicative expectations of the interlocutor, to avoid misunderstanding and discomfort. Translation is not only a linguistic act, but also a cultural one, an act of communication on the border of cultures.

The translation process always has two aspects - language and culture, since they are inseparable. Language and culture are interconnected: language not only expresses cultural reality, but also gives it a form. The meaning of the linguistic element is clear only when it is consistent with the cultural context in which it is used.

Interpreters should pay great attention to differences in the quality and degree of conventionality when interpreting text from the language of one culture to the language of another. One of the main characteristics of the translation is the "double message situation", when the interpreter has to connect the cultural context of the source text and the cultural and communicative features of the translated text. One of the key points when considering translation is the understanding that communication is the interaction of individuals in which communicants act as cultural subjects, 
representatives of a certain linguistic and sociocultural community, and translation as a form of mediation is a means of not only interlanguage, but also intercultural communication (Savushkina, 2013).

One of the fundamental points in considering translation or interpretation is the understanding that communication is the interaction of individuals in which communicants appear as cultural subjects, representatives of a certain linguistic sociocultural community. And translation, as a form of mediation, is both a means of interlanguage and a means of intercultural communication.

The consideration of translation as intercultural communication follows from an understanding of language as a component of culture, as a single socio-cultural unit, and culture as a combination of material and spiritual achievements of a society, including all the multifacetedness of historical, social and psychological features of an ethnic group, its traditions, views, values, institutions, behavior, life, living conditions - in a word, all aspects of its being and consciousness, including language. Understanding this, language is treated as a single socio-cultural entity, reflecting the characteristics of an ethnic group as a bearer of a particular culture, distinguishing it from other cultures.

In this regard, new views on the tasks and the role of the interpreter are being formed. The interest in his activities, the interpretation of which is gradually transforming, is growing. Analyzing the methods of information processing, which is carried out by the interpreter, experts note that he not only interprets the content and communicative intention of the sender, but also looks at them through the eyes of a native speaker. In the translation, two (or more) languages and two cultures that have both common features and national characteristics interact.

The identification of the general, international, universal and private, special and national is of fundamental importance in the study of such a thing as intercultural communication. The task of the interpreter is to convey the meaning of a foreign language text to an addressee who speaks only his native language to inform him about the concepts of a different culture, finding the best way to translate it (Savushkina, 2013).

It is noted that all of the above-mentioned abilities and personal qualities should be developed in the educational process of the university. Developing a specialist in the field of translation at a university is a complex, multi-stage process requiring systemic modernization (Gile, 1995). Often, there is a mismatch between the usual translation qualification requirements and current problems of our time. A low level of competence leads to difficulties in finding a job. Earlier, in the education of translators and interpreters, attention was focused mainly on translation specialization. 
Over the years, a model for training specialists in the field of both translation and interpretation has been developed and methodically substantiated, the linguistic theory of translation and various theories of speech activity serving as the basic foundation. At that time, the quality of training was fully consistent with the needs of the market within the country, but nowadays it is insufficient for intercultural communication.

A new need for expanding the competence of translators/ interpreters has been realized in the context of the adoption of the Federal State Educational Standards of Higher Education in the specialty 45.05.01 Translation and Translation Studies. It defines the current requirements for the results of education, among which - the development of general cultural, general professional, professional and professionally specialized competencies.

Studying the cultural background enriches the inner world of the student through the acquisition of cultural knowledge. The analysis of recent researches has shown that scientists widely consider the modernization process of professional language training taking into account the new cultural paradigm. At the beginning of the $20^{\text {th }}$ century Sergius Hessen (1995) defined education as the value-target object of culture (1995). The concept of cultural appropriateness of education was mentioned by such well-known educators as Friedrich Adolph Wilhelm Diesterweg, Konstantine Ushinsky, Vasiliy Sukhomlinsky (Bolshakova, 2014a). Education and culture correlation is the subject of a number of special researches that determines the development of the educational cultural paradigm. So, Mikhail Bakhtin and Vladimir Bibler developed the dialogue of culture and education concept, according to which the dialogue between people from different cultures is considered as the main form of the existence of culture and the didactic unit of education (Bolshakova, 2014b).

The dialogue of cultures necessitates a reassessment of intercultural contacts and one's own cultural identity based on the ideas of intercultural tolerance, an adequate perception of cultural differences, which under these circumstances are necessary for effective relationships between cultures and mutual understanding between their bearers. It is not the cultures themselves that enter into the dialogue, but people for whom the respective cultures outline specific semantic and symbolic boundaries (Iyeronova, 2008).

The provisions on the need for an interconnected study of foreign languages and culture have long been used in teaching foreign languages. Studying in the educational process the information about countries and nations, the specifics of their culture and mentality increases the cognitive activity of students, helps to improve their communication skills and the development of new communicative skills, motivates and stimulates self-education. 
So, according to Evgeniy Vereshchagin and Vitaliy Kostomarov (Vereshchagin, 2005), each level of the language conveys features of the culture of the host country, i.e. has a regional geographic orientation. At the same time, the formation of communicative competencies is inextricably intertwined with regional geographic knowledge. The study of the cultural background, foreign language culture (Passov, 2002) greatly contributes to the enrichment of the student's inner world by acquiring knowledge about the culture of the native speaker's country, the features of the language being studied, as well as student participation in intercultural communication and the formation of his desire for self-improvement.

Language and culture are characterized by the following general features: 1) language and culture reflects the peoples' worldview; 2) there is always a dialogue between language and culture, since the subject of communication is always the subject of a certain culture; 3) language and culture exist in two forms of individual and social; 4) both language and culture are characterized by normativity, historicism, as well as the mutual inclusion of one sphere in another. But at the same time, language is an integral part of culture, the main tool for its assimilation, the bearer of those features of the national mentality that make it specific.

Thus, in order to help future interpreter effectively carry out their professional activities in various cultural environments, one should educate them in the context of culture, that is orienting the educational programs on the personality and its development. The prior purpose of interpreter's development is his training as a "secondary language personality", since "a professional interpreter is not a key figure in international communication and mutual understanding" (Khaleyeva, 1999). At the same time, the realization of such a goal is possible only through training aimed at mastering a foreign language as a means of intercultural communication in the context of globalization and understanding the values of the linguo-cultural system in all its specifics.

\section{Discussion}

The interest of researchers, who made the main contribution to the development of the problem of professional training of translators, is mainly focused on changing the content of foreign language training. Analysis of the real state of the educational process of translators at Sevastopol State University, as well as the experience of other universities in the country, revealed the following shortcomings in the process of interpreter's training:

- insufficient focus of the educational process on the formation of a moral-oriented personality of the future interpreter;

- low level of knowledge of the cultural characteristics of the countries and inability to apply existing knowledge in practice; 
- inability to carry out intercultural communication at a high level, taking into account linguistic markers of various communication situations;

- difficulties in adapting texts to the realities of the native culture, associated with the need to identify localization objects at the stage of pre-translation text analysis;

- lack of sufficient relation of classroom work, self-guided work and professional training;

- the need to learn two or more foreign languages, due to the current situation in the labour market;

- non-optimal choice of methods and forms of work.

The identified shortcomings are primarily associated with insufficient practical focus on the implementation of the linguo-cultural aspect of translation activity. As a result, we observe a poor development of basic professional competencies, such as: the ability to show psychological stability in extreme conditions, quick switch from one foreign language to another, simultaneous work with several foreign languages, the ability to apply translation transformations in order to achieve a sufficient level of equivalence, and the ability to master various communication registers: official, informal, neutral, the ability to recognize and adequately and use greetings, farewells, emotional exclamations, etc.

Awareness of the need to prepare future interpreter for intercultural communication made it possible to put forward the suggestion that linguo-cultural competence should be formed in the educational process of the university. A linguo-culturally competent interpreter should know the linguistic units of interacting languages, be aware of the lifestyle of interacting societies. Thus, the cultural component is characterized by the level of intercultural competence that means that the interpreter knows:

- major historical events of the foreign language country;

- national holidays;

- traditions and customs;

- psychological and behavioral characteristics of native speakers;

- cultural realia;

- proverbs, sayings, etc.

It will help them to carry out the linguo-cultural aspect of activities more effectively in order to improve intercultural interaction between Russia and other countries (Bolshakova, 2017). 
We define the linguo-cultural competence as an integrative skill of an interpreter, combining linguistic and cultural knowledge, skills, and personal qualities that determine his willingness to perform professional tasks related to the transfer of information from one language to another, taking into account its linguistic and cultural characteristics and with the implementation of intercultural communication in order to establish intercultural ties.

\section{Conclusion}

Thus, we can conclude that the insufficient level of linguo-cultural competence leads to inability to carry out intercultural communication at a high level, taking into account linguistic markers of various communication situations. We also agree with Irina Ieronova (2008), who notes that it is necessary not only to reorganize the process of linguistic preparation, but also to change the attitude towards the interpreter, who is now often regarded as a "staff", and not as a full participant in intercultural communication.

\section{References}

Bolshakova, M.G. (2017). Potentsial obrazovatel'nogo protsessa vuza pri formirovanii lingvokul'turologicheskoy kompetentnosti u budushchikh perevodchikov, izuchayushchikh neskol'ko inostrannykh yazykov. Istoricheskaya i sotsial'no-obrazovatel'naya mysl', 9(6-2), 209-215. (in Russian)

Bolshakova, M.G. (2014a). Developing Cultural and Motivational Components of the LinguoCultural Competence. Vestnik SevNTU. Pedagogika, 144, 29-34.

Bolshakova, M. (2014b). A Linguocultural Approach to Interpreter's Professional Training in the Context of Cultural Dialogue. Interstudia: Cultural Representation in the Era of Globalization. Bacau: Alma Mater, 174-183.

Federal State Educational Standard in 45.05.01 Translation and Translation Studies. Retrieved from: http://fgosvo.ru/news/3/2067

Gessen, S.I. (1995). Osnovy pedagogiki. Vvedeniye v prikladnuyu filosofiyu (in Russian). Moscow.

Gile, D. (1995). Basic concepts and models for interpreter and translator training. Amsterdam/Philadelphia: John Benjamins Publishing company.

Iyeronova, I.Y. (2008). Formirovaniye professional'no-posrednicheskoy kul'tury budushchego perevodchika v kul'turosoobraznoy srede universiteta: $\mathrm{PhD}$ thesis (in Russian). Kaliningrad. 
Kadyrova, K.P. (2018). The role of interpreter in intercultural communication (in Russian). Retrieved from: https://ru.essays.club/Tochnyye-nauki/Kommunikatsii-i-svyaz'/Rol'perevodchika-v-osushchestvlenii-126993.html

Khaleyeva, I.I. (1999). Podgotovka perevodchika kak «vtorichnoy yazykovoy lichnosti» (auditivnyy aspekt). Tetradi perevodchika. Moscow. No.24. P. 64-70. (in Russian)

Komissarov, V.N. (2017). Lingvistika perevoda. Moscow: Librokom.

Ovodova, S.N. (2018). Dialog kul'tur: ob"yasnitel'nyye vozmozhnosti postkolonial'noy optiki v filosofii kul'tury. Vestnik TGU: Tomsk, 46, 86-94. (in Russian)

Passov, Y.I. (2002). Inoyazychnaya kul'tura kak soderzhaniye inoyazychnogo obrazovaniya. Retrieved from: http://www.gramota.ru/biblio/magazines/mrs/28_250. (in Russian)

Savushkina, L.V. (2013). Perevod kak problema mezhkul'turnoy kommunikatsii: PhD thesis. Saransk. (in Russian)

Shveytser, A.D. (1994). Perevod i kul'turnaya traditsiya. Perevod i lingvistika teksta. Moscow: Vserossiyskiy tsentr perevodov, 64-75. (in Russian)

Vereshchagin, Y.M. (2005). Yazyk i kul'tura. Moscow: Indrik. (in Russian) 